\title{
Perpetuating Crises at the Source?: (Inter)Regionalism and Normative Incoherence for Sustainable Migration in Africa
}

\section{Harlan Koff}

To cite this article: Harlan Koff (2020): Perpetuating Crises at the Source?: (Inter)Regionalism and Normative Incoherence for Sustainable Migration in Africa, Politikon, DOI:

10.1080/02589346.2020.1840026

To link to this article: https://doi.org/10.1080/02589346.2020.1840026

\section{Published online: 18 Nov 2020.}

6 Submit your article to this journal

Q View related articles $\sqsubset$

View Crossmark data $\asymp$ 


\title{
Perpetuating Crises at the Source?: (Inter)Regionalism and Normative Incoherence for Sustainable Migration in Africa
}

\author{
Harlan Koffa,b,c \\ aDepartment of Geography and Spatial Planning, University of Luxembourg, Esch-Belval, Luxembourg; \\ ${ }^{b}$ Instituto de Ecología, A. C. (INECOL), Xalapa, Mexico; 'Department of Politics and International Relations, \\ University of Johannesburg
}

\begin{abstract}
In response to the 2015-2016 migration crisis, the European Union established the Emergency Trust Fund for Africa that aimed 'to address the root causes of instability, forced displacement and irregular migration and to contribute to better migration management.' This article questions the logic of this approach to migration management by asking whether African regions can 'better manage migration.' The article examines the normative bases of migration policies amongst the African Union (AU) and six regional economic communities (RECs), as well as the normative bases of the development strategies pursued by the AU and these RECs. The article proposes normative policy coherence for development as an approach to better understand the relationships between regional integration, sustainable development and migration management in Africa.
\end{abstract}

\section{Introduction}

This article is a comparative analysis of migration and development policies amongst Africa's regional economic communities (RECs). The article compares their declared policy objectives in relation to transformative development. The roots of this analysis are found in the 2015-2016 'migration crisis,' during which almost two million migrants/asylum seekers entered the European Union (EU) (European Commission 2016) and 8470 people drown in the Mediterranean Sea (International Organisation for Migration undated). The EU's only unified responses were the reinforcement of border controls and the provision of large-scale funding for transit states and sending countries for the securitisation of migration (Moldes-Anaya, Aguilar, and Bautista 2019). The most ambitious investment was the EU Emergency Trust Fund for Africa that aimed 'to address the root causes of instability, forced displacement and irregular migration and to contribute to better migration management.' This article questions this logic by asking: Do African regions promote sustainable migration management? which would be a necessary element of the EU's claim. This article addresses this question through the lens of normative policy coherence for development (PCD) defined as the alignment of policies with core values on which democratic political systems are established, such as human rights, democracy, gender equality, etc. (Koff and Maganda 2016; Häbel 2020). Normative PCD examines non-development policy arenas and their impacts on the normative objectives of sustainable development strategies. These norms are codified in

CONTACT Harlan Koff harlan.koff@uni.lu Department of Geography and Spatial Planning, Maison des Sciences Humaines, 11, Porte des Sciences, L-4366 Esch-Belval, Luxembourg 
constitutional treaties, yet they are rarely transcribed into migration policy frameworks (Koff 2017b).

Since the establishment of the Sustainable Development Goals (SDGs) in 2015, all world regions are meant to be pursuing transformative development defined as providing for the needs of local populations while addressing power imbalances at the supranational level (see Martens 2015). The Goals state: 'We are determined to take the bold and transformative steps which are urgently needed to shift the world onto a sustainable and resilient path. As we embark on this collective journey, we pledge that no one will be left behind' (United Nations n.d.). Regions are specifically mentioned throughout the document as identified facilitators for the achievement of sustainability along with member states. For example, Article 21 states:

We acknowledge also the importance of the regional and sub-regional dimensions, regional economic integration and interconnectivity in sustainable development. Regional and subregional frameworks can facilitate the effective translation of sustainable development policies into concrete action at national level. (United Nations n.d.)

This article comparatively analyses migration and development policies amongst Africa's regional economic communities (RECS) and compares their declared policy objectives in relation to transformative development. It contends that the development pursued by African RECs undermines sustainable migration systems because it does not normatively promote transformative development as defined by the SDGs. Even though regions do not implement policies in many sectors, such as health, education and social services, they do establish guidelines for member states which are meant to guide development processes.

The article is divided into five parts. Following this introduction, part two reviews the literature on regional integration, migration and development in Africa. Part three then introduces the notion of normative policy coherence for development within this context. Part four analyses the migration regimes pursued by Africa's RECs and discusses them within the framework of transformative sustainable development. This section then compares the economic models promoted by RECs in Africa and discusses their impacts on migration systems. Finally, part five presents the conclusions.

\section{Methods: research design, data collection and analysis}

The research presented in this article examines the migration management and development strategies of seven African regional organisations: the African Union (AU); Common Market for Eastern and Southern Africa (COMESA); East African Community (EAC); Economic Community of Central African States (ECCAS); Economic Community of West African States (ECOWAS); Intergovernmental Authority on Development (IGAD), and Southern Africa Development Community (SADC). A list of member states of each regional organisation has been compiled in the appendix. The Arab-Maghreb Union and the Community of Sahel-Saharan States (CEN-SAD), the two remaining African regional economic communities, have not been included in this study for two reasons. First, these organisations have largely been dormant in recent years and they have not adopted any concrete migration instruments. Second, due in part to their current conditions, policy information is not publicly available. 
This article is based on a review of policy documents and websites of African regional organisations as well as secondary literatures on migration and development collected from academic libraries and the websites of regional think tanks. Official documents from the EU and United Nations agencies, such as the International Organisation for Migration have also been consulted to complement those collected from African regional organisations. Data was collected from these sources on migration policies, as well as seven key sustainable development policy sectors: security, trade and economic development, finance, infrastructure, natural resources, social protection, agriculture and food policy. According to the logic of normative policy coherence for development, transformative development objectives should permeate both development and non-development policy arenas. For sustainable migration management to occur, transformative development objectives need to be pursued not only in migration affairs, but also in complementary policy dimensions (see Deacon and Nita, 2013). Consequently, data was analysed by comparing stated policy objectives to the normative framework presented in the SDGs. This is explained in detail below.

\section{Literature review: migration and regionalism in Africa}

Africa is widely recognised as a continent characterised by mobility and migration (see Degli Uberti et al. 2015; Espinosa 2013). Scholars and international organisations, such as the International Organisation for Migration and the World Bank have noted that, like other regions, up to $70 \%$ of international migration from sub-Saharan countries occurs on the continent (World Bank 2010). According to the 2017 United Nations Population and Vital Statistics Report, 19 million people have migrated between African states (United Nations 2017). Degli Uberti et al. $(2015,77)$ argue that 'being mobile' is not an exception but rather a 'way of life' for millions of Africans who share a certain 'culture of migration.'

Because there is so much human movement on the African continent, many scholars have contended that generalised migration paradigms that have emerged in Western literatures do not apply to Africa. For example, Gagnon and Khoudour-Castéras argue that assimilation and multiculturalism, two concepts that guide Western integration debates, cannot be applied to African contexts due to the porous nature of African borders, the limited economic benefits of African welfare regimes and the presence of simultaneous identities amongst African populations (Gagnon and Khoudour-Castéras 2012). Similarly, African scholars of migration, such as Oucho (2013) have noted that the word 'crisis' in association with migration has different meanings on the continent than it does in the EU and the United States.

Regional integration is a key theme in the literature on migration in Africa. Specifically, the literature on African migration and regional integration focuses heavily on the right to free movement. In fact, all of the major regional economic communities in Africa officially support the right to free movement amongst their development strategies but operationalising this right remains a challenge. By definition, the $A U$ has not implemented the right to free movement because the $A U$ does not apply law directly, it defines supranational norms that guide the RECs and their member states. Consequently, when the RECs do not implement policies, such as the right to free movement, AU norms remain conceptual with limited policy impact. 
The literature on RECs and immigration provides three explanations for the lack of implementation of the right to free movement. First, scholars have linked this inaction to the general structural weakness of RECs in Africa's governance systems. Nita (2013) for example, comparatively analyses the right to free movement amongst eight RECs in Africa and she documents how this right is integrated into all regional legal frameworks on the continent. However, Nita (2013) also illustrates how the 'right to employment' is not operationalised by any RECs or their member states, which fundamentally undermines the right to free movement. Various case studies of specific regions reflect this conclusion. Oucho (2013) contends that the EAC should provide a blueprint for the implementation of the right to free movement because it is the oldest REC in Africa with the most developed regional system. He documents how attempts to implement the free movement of people have led to xenophobia and other unintended consequences. In his study of Central Africa, Nono (2013) shows how the right to free movement is disrupted by numerous systemic failures of the ECCAS including lack of infrastructure networks, insecurity, poverty, supply-side weaknesses in basic social services, weak economies, and the egotism of some leaders who are opposed to the opening of their borders to neighbouring countries. Adeniran (2014) and Eriksson (2013) document similar problems in ECOWAS. Abebe (2017) details how overlapping regional organisations and the multiplicity of memberships undermines the operationalisation of 'the free movement of people' principle more generally. Compton (2013) and Iroanya, Dzimiri, and Phaswana (2018) examine the ineffectiveness of regional human rights systems in Africa. Crush and Pendleton (2004) discuss the 'lack of regional consciousness' in SADC as an obstacle to free movement in that REC.

Building on this literature regarding the structural weakness of REC governance, the second group of studies in this field introduces a normative element to this scholarship. For example, Hujo (2013) contends that regional governance mechanisms for migration need to be supported by activity in related policy arenas, such as labour market policies and social protection. She shows how this has not occurred in Africa because RECs have not fully adopted principles, such as equal treatment and non-discrimination, which expand social contracts beyond national borders. This has been prevented by (1) nationalist backlash which has interrupted the consolidation of African regions, (2) practices and funding commitments that lag behind legal rights and standards and (3) de-prioritisation of the 'social question' which has not been adequately integrated into policy agendas and development strategies. Likewise, Moore (2013) has shown how regional integration and social cohesion remain disconnected on the African continent.

This point is further developed by Deacon, Fioramonti, and Nita (2013) who argue that access to social security, social assistance, health and education services are the keys to facilitating free movement within regions. Moreover, they contend that social provisions by all cross-border movers within a region is the key to achieving real regional social integration. The authors demonstrate how this has been prevented by the 'no recourse to public funds for migrants' discourse in South Africa and SADC in general. The emergence of welfare chauvinism in Africa has also been documented by Nhengu (2020) whose study demonstrates how migration policy design from micro to macro levels does not align with ratified international protocols on health, resulting in multiple vulnerabilities of female migrants. 
Finally, a third body of scholarship has examined the lack of integration of migration/ free movement in sustainable development strategies on the African continent. Bakewell (2007) specifically recognises a 'sedentary bias' amongst development actors in Africa. He shows how programs pursued by development agencies promote a sedentary model of development that aims to enable people to achieve a better quality of life at 'home'. Migration is actually considered to be an indicator of policy failure within this logic which is antithetical to the right to free movement. Awumbila (2017) examines migration in Africa in terms of urban growth and the negative social impacts of migration on African cities. Flahaux and De Haas (2016) study the drivers of migration in Africa and they contend that rising capabilities amongst migrants push inter-regional migration to Europe. In turn, this negatively effects the link between intra-regional migration and sustainable development.

Together, these three approaches to regional integration, migration and sustainable development in Africa highlight the disconnect between migration policies and transformative development as promoted by the SDGs. This normatively undermines the sustainability of African migration systems. Drawing on previous research conducted on other world regions, this article articulates this position through the conceptual lens of normative policy coherence for development.

\section{Conceptual approach: normative PCD}

PCD has been established by the global development community for the purpose of promoting development through international organisations and their member states. It has evolved significantly since it was first proposed by the Organisation for Economic Cooperation and Development's (OECD) Development Assistance Committee in 1991. The EU adopted PCD shortly afterward, in 1993 through the Maastricht Treaty. During this initial period, PCD was defined as

working to ensure that the objectives and results of a government's (or institution's) development policy are not undermined by other policies of that same government (or institution), which impact on developing countries, and that these other policies support development objectives where feasible. (OECD 2005, 28)

Today, the context surrounding PCD has evolved. It has received significant international political attention for its central role in the 2030 Sustainable Development Agenda (Graham and Graham 2019). PCD is part of Target 17.14, focusing on governance of sustainability partnerships for achievement of the SDGs. For these reasons (among others), PCD has moved from the margins to the forefront of sustainable development debates and it has become a pillar of the 2030 agenda.

The definition of PCD has broadened as well. According to the newest OECD definition, PCD is

an approach to integrate the dimensions of sustainable development throughout domestic and international policy-making. Its objectives in the context of the 2030 Agenda are to advance the integrated implementation of the 2030 Agenda by: 1) Fostering synergies and maximizing benefits across economic, social and environmental policy areas; 2) Balancing domestic policy objectives with internationally recognised sustainable development goals; and 3) Addressing the transboundary and long-term impacts of policies, including those likely to affect developing countries. (OECD 2019) 
As international organisations have worked to implement PCD as a pillar of the SDGs, academic perspectives have been very critical of the implementation of the concept. Earlier studies of PCD (Forster and Olav Stokke 1999; Hoebink 2004) aimed at classifying this term through typologies and understanding its role in development cooperation. Empirical studies examined implementation of PCD (or lack thereof) in specific policy arenas such as security (Picciotto 2004), trade (Grabel 2007), agriculture (Matthews 2008), etc., often with highly critical evaluations of donor policies. Grabel (2007) has indicated that PCD is a concept that has been abused by international organisations.

Often, PCD has been criticised as an empty political discourse that is rarely implemented by powerful donor states and regions (notably the EU) (Häbel 2020), or an instrument for controlling poor countries through coordinated policies (Thede 2013). Other studies have raised important analytical questions about the concept. Carbone (2008) correctly contended that PCD can be viewed as both a decisionmaking process and a policy outcome. More recently, Carbone and Keijzer (2016) argued that the EU has in fact pursued the development of institutional reform over policy effectiveness. Häbel (2020) has studied EU policy communities in-depth and she contends that PCD is often undermined as a normative tool because policy communities do not interact and their policy objectives diverge. Moreover, Häbel contends that key EU norms, such as gender equality, human rights, political freedom, etc. are undermined by political interests or economic exchanges. Similarly, Koff, Challenger, and Portillo (2020) highlight PCD's institutional character which limits its normative impact due to an absence of avenues for citizen participation.

In the field of migration studies, the literature on PCD has been equally critical of the normative contributions that this tool has made to transformative development. NybergSorensen, Van Hear, and Engberg-Perdersen studied the coherence between 'relief, recovery, development and conflict prevention' $(2002,3)$ in relation to migration through a comparative analysis of PCD in both development and humanitarian aid which criticised the coordination of migration policies with these peacebuilding objectives. More recently, Nyberg-Sorensen has integrated security into her discussions of PCD and migration. In 2012, she identified policy incoherence resulting from the intersection of: (1) rising poverty and insecurity in the South; (2) the continuous demand for cheap labour in the North; and (3) border enforcement initiatives that increase risk and vulnerability in migration regimes (Nyberg-Sorensen 2012). Broadening this perspective, Koff (2017b) has comparatively examined the securitisation of development aid by both the EU and the United States as a means 'to address migration at its source'. He contends that these postures have undermined normative PCD in global migration affairs. Koff has also illustrated how these policy positions have normatively impacted diaspora philanthropy (2017a) which has affected development finance in many sending states.

Despite these critical narratives, other authors observe significant value of PCD for developing/emerging countries and regions, especially those in Africa. Zeigermann (2020) contends that PCD provides a basis for the promotion of human security in fragile states because it addresses policy interlinkages and unintended consequences, thereby resolving development-security challenges. Mbanda and Fourie (2019) contend that South African policymakers have emphasised the need to prioritise the SDGs' targets in terms of national priorities, thus highlighting the need for normative coherence in the application of PCD. Building on this argumentation, this article empirically examines 
normative policy coherence between migration and sustainable development within the African Union and Africa's RECs.

\section{Regional development policies and migration in Africa}

As mentioned above, this article derives from the EU's contention, through the Emergency Trust Fund for Africa (amongst other measures) that migration can be better managed at its source. Of course, the key concept to be questioned here asks, what does 'better management of migration' mean? There is a vast literature on EU migration strategies that illustrates the organisation's commitment to securitisation of migration (see Barana 2017; Hintjens 2019; Koff, Akashi, and Okabe 2018). However, given the commitments that regional organisations have made to sustainable development and more particularly to the implementation of the SDGs, the notion of 'better management of migration' should be linked to the transformative development pursued by the SDGs. Even though there is no migration goal specified amongst the SDGs, the 2030 Agenda for Sustainable Development normatively integrates migration as a transversal phenomenon that is pertinent to all of the SDGs. More importantly, the 2030 Agenda's core principle stating 'leave no one behind' includes migrants and migration is primarily referenced in this agenda through target 10.7 aimed at facilitating orderly, safe, regular and responsible migration and mobility of people. This target is part of Goal 10 that aims to reduce inequalities.

African regions have adopted strong positions in support of the 2030 Agenda on Sustainable Development. These regions have made normative commitments to the SDGs with particular focus on inclusive development and the fight against poverty. For example, according to the African Union's Agenda 2063:

Africa is expected to show improved standards of living; transformed, inclusive and sustained economies; increased levels of regional and continental integration; a population of empowered women and youth and a society in which children are cared for and protected; societies that are peaceful, demonstrate good democratic values and practice good governance principles which preserve and enhance Africa's cultural identity. (African Union n.d.)

Similarly, the SADC Regional Indicative Strategic Development Plan (RISDP), which transcribes the SDGs into SADC policy, contends that member states 'need to pay special attention to the voices of the most marginalised segments of society' (SADC 2017).

Are African regional migration management strategies normatively coherent with these development objectives? Table 1 presents migration management strategies for the $A U$ and six RECs. This table highlights both a division and a general weakness of regional migration strategies. The division regards the divergence between the $A U$ and the African sub-regions in migration affairs. The AU provides a normative voice linking migration to transformative development by highlighting 'safe, orderly and dignified migration' as well as the socio-economic well-being of migrants. The AU also has established regional institutional mechanisms for migration management which is symbolically important.

The African RECs included in this study demonstrate a decidedly different approach to migration management. All of them support free movement of people but only within the framework of free trade and the establishment of common markets, thus normatively 
Table 1. Regional migration management strategies in Africa.

Regional
organisation

AU Migration Policy Framework: Migration Governance;

Labour Migration and Education; Diaspora

Engagement; Border Governance; Irregular Migration:

Forced Displacement: Internal Migration; Migration and Trade

COMESA

The main objective of the COMESA MIDCOM is to provide a platform for informal and non-binding dialogue on issues and opportunities related to migration management thereby improving the capacity of the governments to better manage migration, network building through regular

meetings, including substantial progress towards

harmonised data collection systems and harmonised immigration policy and legislation.

EAC Free movement; adoption of common border

management; common standard system of issuing identification documents; common standard travel document; community employment rights; common recognition of academic and professional

qualifications; harmonisation of education, labour

laws and standards in order to facilitate free

movement; common mechanisms for management of refugees.

ECCAS

Migration Dialogue for Central African States (MIDCAS): promoting the common interests of ECCAS member states to facilitate consultations and intra-regional cooperation on migration issues within the ECCAS region as well as with other $\mathrm{AU}$ regional economic communities (AU RECs).

Objectives

Implementation mechanism

Better migration governance as the overarching objective of the MPFA aims at facilitating safe, orderly and dignified migration. It advocates for the socioeconomic well-being of migrants and society through compliance with international standards and laws. The security of migrants' rights and addressing the migration aspects of crises are key elements.

Additional focus on migration and development and combatting human trafficking

Promotion of free movement of persons, services, labour, rights of establishment and residence in line with common market

Free movement of persons, labour and services and to ensure the enjoyment of the right of establishment and residence of their citizens within the community.

Free movement of persons for common market

Member states
The Social Affairs Department promotes the work of the $\mathrm{AU}$ in the area of migration, labour and employment and the Political Affairs Department is working with members states to implement the AU Protocol on Free Movement of Persons, Rights of Residence and Right of Establishment.

Member states

Member states 
Table 1. Continued.

Regional

organisation

ECOWAS

Migration strategies

Objectives

Free movement of persons within the ECOWAS; Lega migration towards other regions of the world contributes to ECOWAS Member States' development; Combating human trafficking is a moral and

humanitarian imperative; Harmonising policies ECOWAS Member States are reaffirming their commitment to ensure policy coherence; Protection of the rights of migrants, asylum seekers and refugees;

Recognising the gender dimension of migration Regional Migration Policy Framework (IRMPF) IGAD Refugees Programme - harmonisation of refugee policy

Free Movement of Persons

SADC

Free Movement of Persons

immigration logistical systems, which may include

clearance procedures for SADC nationals (Article 3.4).

Institutional frameworks that facilitate unimpeded

access and travel between Member States in order to support regional development corridors.

\section{Policy Coherence at various levels: - bilatera}

agreements linking different ECOWAS Member State

and third countries, with ECOWAS community text:

Harmonise economic, trade and development aid

policies of the North with migratory policies of said

countries; Harmonise national migration

management policies with sector development.

Ensure migration is voluntary and legal through

methods that respect the human rights of migrants

and collaboration among actors, including migrants,

countries of origin, transit and destination.

Free Movement of People and Prevention of Crossborder criminal activity
Implementation mechanism

ECOWAS Common Approach to Migration Management (ECOWAS Commission and member states)

Regional Deliberation Platforms; Ministerial Committee on Migration (MCM) and Regional Migration

Coordination Committee (RMCC) but member states implement migration management

SADC Organ on Politics, Defence and Security in association with member states

Source: Table compiled by author based on policy documents. 
diminishing the role of transformative sustainable development in migration affairs. Only IGAD explicitly mentions human rights in its platform and the EAC has adopted a common refugee policy. SADC, on the other hand, has forwarded a management strategy that openly securitises migration and pursues border controls through the justification of addressing cross-border criminal activities.

In terms of implementation, the normative significance of regional integration has also been limited due to the aforementioned weakness of African regional institutions. Only ECOWAS, IGAD and SADC have established regional organs for migration management and all three are characterised by shared responsibility with member states. In the case of IGAD and ECOWAS, regional bodies normatively pursue sustainable migration strategies but member states dominate the governance relationship and they often prevent the implementation of these regional policies. In SADC, the regional body that addresses migration is the SADC Organ on Politics, Defence and Security which securitises migration rather than embedding it in regional sustainable development programs.

Of course, migration policies are not formulated in a vacuum. The EU's argument that migration can be better managed at its source assumes that African governments are well-positioned to pursue sustainable development in general. Tables 2 through 4 question this assumption. Table 2 compares the defining characteristics of seven African regional development strategies in seven key policy sectors. These sectors were chosen because normative coherence for development examines the interaction between development and non-development policies and key norms. Some policy arenas, such as natural resource management, social protection and agriculture and food policy are generally considered more relevant for sustainable development. Security, finance, trade and economic policy and infrastructure are usually viewed as 'non-sustainable development policies' at the regional level even though they have been incorporated into the SDGs.

Table 3 introduces a scale for the measurement of normative policy coherence for development. The scale examines whether the normative bases of policies mutually reinforce or clash with transformative sustainable development norms as defined above. It is based on the work proposed by Nilsson et al. (2018) which maps the interactions between the SDGs. In order to adapt this scale to norms, policies are analysed in terms of intentional/unintentional and direct/indirect impacts. In cases where policies intentionally and directly reinforce transformative development norms, +3 is assigned. When policies intentionally and directly undermine transformative development then -3 is assigned. The values in between represent mixed relationships as explained in the table.

Table 4 implements empirical analysis through the application of the scale described in Table 3 to the regional policy characteristics described in Table 2. The table clearly highlights a limited normative commitment to transformative sustainable development among African regional organisations. Only ECOWAS and the EAC demonstrate positive normative commitments to transformative sustainable development in their general policy frameworks. Similarly, even though African regional natural resource management, social protection and agriculture and food policies generally promote sustainability, these synergies with transformative development are undermined by economic and trade policies, finance, infrastructure and security. Consequently, it would seem paradoxical to expect African regions to promote sustainable migration management, as the EU does, when their policy frameworks do not normatively align with the SDGs. In other words, 
Table 2. Defining characteristics of African regional development strategies is seven key policy sectors.

\begin{tabular}{|c|c|c|c|c|c|c|c|}
\hline & Security policy & $\begin{array}{c}\text { Trade and economic } \\
\text { development }\end{array}$ & Finance & Infrastructure & Natural resources & Social protection & $\begin{array}{l}\text { Agriculture and food } \\
\text { policy }\end{array}$ \\
\hline African Union (AU) & $\begin{array}{l}\text { Implement a } \\
\text { dialogue-centred } \\
\text { approach to conflict } \\
\text { prevention and } \\
\text { resolution of conflicts } \\
\text { and establishing of a } \\
\text { culture of peace and } \\
\text { tolerance nurtured in } \\
\text { Africa's children and } \\
\text { youth through peace } \\
\text { education }\end{array}$ & $\begin{array}{l}\text { African Continental Free } \\
\text { Trade Area: intra-African } \\
\text { trade and boosting } \\
\text { Africa's trading position } \\
\text { in the global market by } \\
\text { strengthening Africa's } \\
\text { common voice and } \\
\text { policy space in global } \\
\text { trade negotiations. }\end{array}$ & $\begin{array}{l}\text { The creation of African } \\
\text { Continental Financial } \\
\text { Institutions aims at } \\
\text { accelerating } \\
\text { mobilisation of } \\
\text { resources and } \\
\text { management of the } \\
\text { African financial sector. } \\
\text { African Investment } \\
\text { Bank and Pan African } \\
\text { Stock Exchange; the } \\
\text { African Monetary Fund } \\
\text { and the African Central } \\
\text { Bank. }\end{array}$ & $\begin{array}{l}\text { The Programme for } \\
\text { Infrastructure } \\
\text { Development in Africa } \\
\text { (PIDA) which provides a } \\
\text { common framework for } \\
\text { infrastructure necessary for } \\
\text { more integrated transport, } \\
\text { energy, ICT and trans- } \\
\text { boundary water. }\end{array}$ & $\begin{array}{l}\text { African Commodities } \\
\text { Initiative: } \\
\text { Transforming Africa } \\
\text { from a raw materials } \\
\text { supplier by enabling } \\
\text { countries to add } \\
\text { value, extract higher } \\
\text { rents from } \\
\text { commodities, } \\
\text { integrate into global } \\
\text { value chains promote } \\
\text { diversification } \\
\text { anchored in value } \\
\text { addition and local } \\
\text { content } \\
\text { development. }\end{array}$ & $\begin{array}{l}\text { AU's strategy for } \\
\text { Gender Equality and } \\
\text { Women's } \\
\text { Empowerment (GEWE) } \\
\text { to ensure the inclusion } \\
\text { of women in Africa's } \\
\text { development agenda.; } \\
\text { Continental Education } \\
\text { Strategy for Africa; } \\
\text { nutrition levels on the } \\
\text { continent and has } \\
\text { undertaken specific } \\
\text { activities such as the } \\
\text { Cost of Hunger in Africa } \\
\text { Study }\end{array}$ & $\begin{array}{l}\text { The Comprehensive } \\
\text { African Agricultural } \\
\text { Development } \\
\text { Programme (CAADP) } \\
\text { aims to help African } \\
\text { countries eliminate } \\
\text { hunger and reduce } \\
\text { poverty by raising } \\
\text { economic growth } \\
\text { through agriculture-led } \\
\text { development. Great } \\
\text { Green Wall (GGW) } \\
\text { initiative the AU aims to } \\
\text { end or reverse land } \\
\text { degradation, loss of } \\
\text { biodiversity in African } \\
\text { drylands and to ensure } \\
\text { that ecosystems are } \\
\text { resilient to climate } \\
\text { change }\end{array}$ \\
\hline $\begin{array}{l}\text { Common Market for } \\
\text { Eastern and } \\
\text { Southern Africa } \\
\text { (COMESA) }\end{array}$ & $\begin{array}{l}\text { Issues of peace and } \\
\text { security are } \\
\text { addressed in order to } \\
\text { reinforce COMESA } \\
\text { primary objective of } \\
\text { strengthening } \\
\text { economic integration } \\
\text { and development }\end{array}$ & $\begin{array}{l}\text { Promote self-sustained } \\
\text { and balanced growth; } \\
\text { Increase the availability } \\
\text { of industrial goods and } \\
\text { services for intra- } \\
\text { Common Market; } \\
\text { Establishment of Special } \\
\text { Economic Zones to } \\
\text { attract FDI: }\end{array}$ & $\begin{array}{l}\text { Create an enabling } \\
\text { legal, regulatory and } \\
\text { institutional business } \\
\text { environment to attract } \\
\text { FDI: Promote diaspora } \\
\text { resources in the } \\
\text { industrialisation drive, }\end{array}$ & $\begin{array}{l}\text { Effectively address } \\
\text { constraints related to the } \\
\text { improvement of } \\
\text { infrastructure and services } \\
\text { in the region in order to } \\
\text { reduce the cost of doing } \\
\text { business and also and to } \\
\text { enhance competitiveness, }\end{array}$ & No regional initiative & $\begin{array}{l}\text { Mainstream gender as a } \\
\text { crosscutting issue; } \\
\text { Mainstream cross- } \\
\text { cutting issues such as } \\
\text { HIV and AIDS in order } \\
\text { to control such } \\
\text { epidemics. }\end{array}$ & $\begin{array}{l}\text { Public and private sector } \\
\text { investment policies, } \\
\text { incentives and } \\
\text { regulatory frameworks } \\
\text { to enhance priority } \\
\text { livestock value chains; } \\
\text { Enhance environmental } \\
\text { health and ecosystem } \\
\text { services; Manage climate } \\
\text { change and variability } \\
\text { risks; Support } \\
\text { sustainable fisheries }\end{array}$ \\
\hline $\begin{array}{l}\text { East African } \\
\text { Community (EAC) }\end{array}$ & $\begin{array}{l}\text { Sectoral Council on } \\
\text { Interstate Security } \\
\text { was established to } \\
\text { address: Illicit Drug } \\
\text { Trafficking Small } \\
\text { Arms and Light } \\
\text { Weapons; Co- }\end{array}$ & $\begin{array}{l}\text { Rationalise investments } \\
\text { and the full use of } \\
\text { established industries so } \\
\text { as to promote efficiency } \\
\text { in production, as well as } \\
\text { harmonise and } \\
\text { rationalise investment }\end{array}$ & $\begin{array}{l}\text { The integration of the } \\
\text { EAC stock exchanges; } \\
\text { Develop common } \\
\text { automated trading and } \\
\text { clearing platforms; } \\
\text { Cross-list shares to } \\
\text { increase private capital }\end{array}$ & $\begin{array}{l}\text { Coordinating, harmonising } \\
\text { and complementing } \\
\text { transport and } \\
\text { communications policies; } \\
\text { Improving and expanding } \\
\text { the existing transport and } \\
\text { communication links; and }\end{array}$ & $\begin{array}{l}\text { Key priorities of the } \\
\text { sector include Climate } \\
\text { Change adaptation } \\
\text { and mitigation, } \\
\text { natural resource } \\
\text { management and } \\
\text { biodiversity }\end{array}$ & $\begin{array}{l}\text { Five standing Technical } \\
\text { Working Groups } \\
\text { responsible for } \\
\text { handling detailed } \\
\text { health matters: } \\
\text { Medicines and Food } \\
\text { Safety; Control and }\end{array}$ & $\begin{array}{l}\text { The Agriculture and } \\
\text { Rural Development } \\
\text { Strategy outlines the } \\
\text { strategic interventions } \\
\text { identified for the } \\
\text { acceleration of } \\
\text { agricultural sector }\end{array}$ \\
\hline
\end{tabular}


Table 2. Continued.

\begin{tabular}{|c|c|c|c|c|c|c|c|}
\hline & Security policy & $\begin{array}{c}\text { Trade and economic } \\
\text { development }\end{array}$ & Finance & Infrastructure & Natural resources & Social protection & $\begin{array}{l}\text { Agriculture and food } \\
\text { policy }\end{array}$ \\
\hline & $\begin{array}{l}\text { operation in Police } \\
\text { Matters. }\end{array}$ & $\begin{array}{l}\text { incentives with a view } \\
\text { to promoting the } \\
\text { Community as a single } \\
\text { investment area. }\end{array}$ & $\begin{array}{l}\text { flows within the } \\
\text { region. }\end{array}$ & $\begin{array}{l}\text { establishing new ones as a } \\
\text { means of furthering the } \\
\text { physical cohesion of the } \\
\text { Partner States, so as to } \\
\text { facilitate and promote the } \\
\text { movement of traffic within } \\
\text { the Community. }\end{array}$ & $\begin{array}{l}\text { conservation, disaster } \\
\text { risk reduction and } \\
\text { management, and } \\
\text { pollution control and } \\
\text { waste management. . }\end{array}$ & $\begin{array}{l}\text { Prevention of Sexually } \\
\text { Transmitted Infections } \\
\text { (STIs), HIV and AIDS; } \\
\text { Control and Prevention } \\
\text { of Communicable and } \\
\text { Non-Communicable } \\
\text { Diseases; Health } \\
\text { Research, Policy and } \\
\text { Health Systems } \\
\text { Development; and, } \\
\text { Reproductive, Child, } \\
\text { Adolescent Health and } \\
\text { Nutrition; } \\
\text { Mainstreaming gender } \\
\text { social Cooperation in } \\
\text { welfare, employment, } \\
\text { poverty alleviation and } \\
\text { working conditions; } \\
\text { Education; Social } \\
\text { integration }\end{array}$ & $\begin{array}{l}\text { development: Improving } \\
\text { Food Security; } \\
\text { Accelerating irrigation } \\
\text { development; } \\
\text { Strengthening Early } \\
\text { Warning Systems; } \\
\text { Research, Extension and } \\
\text { Training; Increasing Intra } \\
\text { and Inter Regional Trade } \\
\text { and Commerce; Physical } \\
\text { Infrastructure and } \\
\text { Utilities }\end{array}$ \\
\hline $\begin{array}{l}\text { Economic } \\
\text { Community of } \\
\text { Central African } \\
\text { States (ECCAS) }\end{array}$ & $\begin{array}{l}\text { Security Council in } \\
\text { Central Africa } \\
\text { (COPAX) with three } \\
\text { key instruments, the } \\
\text { Commission for } \\
\text { Defence and Security, } \\
\text { the Central African } \\
\text { Early Warning System } \\
\text { and the Central } \\
\text { African Multinational } \\
\text { Force. }\end{array}$ & $\begin{array}{l}\text { Given the foundation of } \\
\text { ECCAS, trade and } \\
\text { market integration is its } \\
\text { core objective. }\end{array}$ & $\begin{array}{l}\text { Strengthen tax policy } \\
\text { by raising indirect tax } \\
\text { rates (value-added tax } \\
\text { and excise duties) and } \\
\text { reduce direct taxation; } \\
\text { Improve public } \\
\text { expenditure }\end{array}$ & $\begin{array}{l}\text { ECCAS Consensus Blue } \\
\text { Print on Transport in } \\
\text { Central Africa: linking } \\
\text { capitals in short-term and } \\
\text { people and goods in long- } \\
\text { term; Consolidated } \\
\text { Transport Development } \\
\text { Plan for Central Africa } \\
\text { (PDCT-AC), which includes } \\
14 \text { priority projects } \\
\text { including all transport } \\
\text { infrastructure that supports } \\
\text { the international trade of } \\
\text { States in the region; Central } \\
\text { African Energy Pool (PEAC) } \\
\text { - regional energy market }\end{array}$ & $\begin{array}{l}\text { Green Economy; Eco- } \\
\text { security - role of } \\
\text { natural resources in } \\
\text { conflict; Pursues the } \\
\text { overall objective of } \\
\text { enhancing the value } \\
\text { of natural resources in } \\
\text { order to increase their } \\
\text { contribution to the } \\
\text { economy of the } \\
\text { States and improve } \\
\text { decision-making; The } \\
\text { Central African Forest } \\
\text { Commission } \\
\text { (COMIFAC) is the } \\
\text { world's largest and } \\
\text { most important } \\
\text { conservation and } \\
\text { sustainable } \\
\text { management body } \\
\text { for the forest and } \\
\text { savannah ecosystems } \\
\text { of the Congo Basin. }\end{array}$ & $\begin{array}{l}\text { No relevant regional } \\
\text { policy }\end{array}$ & $\begin{array}{l}\text { Regional Investment } \\
\text { Programme for } \\
\text { Agriculture, Food and } \\
\text { Nutrition; Security as } \\
\text { part the regional CAADP } \\
\text { process, the Regional } \\
\text { Programme for Food } \\
\text { Security, the Regional } \\
\text { Cotton-Textile Strategy } \\
\text { and the establishment of } \\
\text { a Regional Animal } \\
\text { Health Centre }\end{array}$ \\
\hline
\end{tabular}

movement of traffic within

anagement, and

Warning Systems;

Desearch, Extension and

Research, Policy and

and Inter Regional Trade and Commerce; Physical

Nutrition;

king conditions;

Green Economy; Eco-

security - role of

enhancing the value

Transport Development of natural resources in

Plan for Central Africa order to increase their

economy of the

infrastructure that sup

the international trade of Central African Forest

Commission

African Energy Pool (PEAC) (COMIFAC) is the

sustainable

for the forest and

of the Congo Basin. 


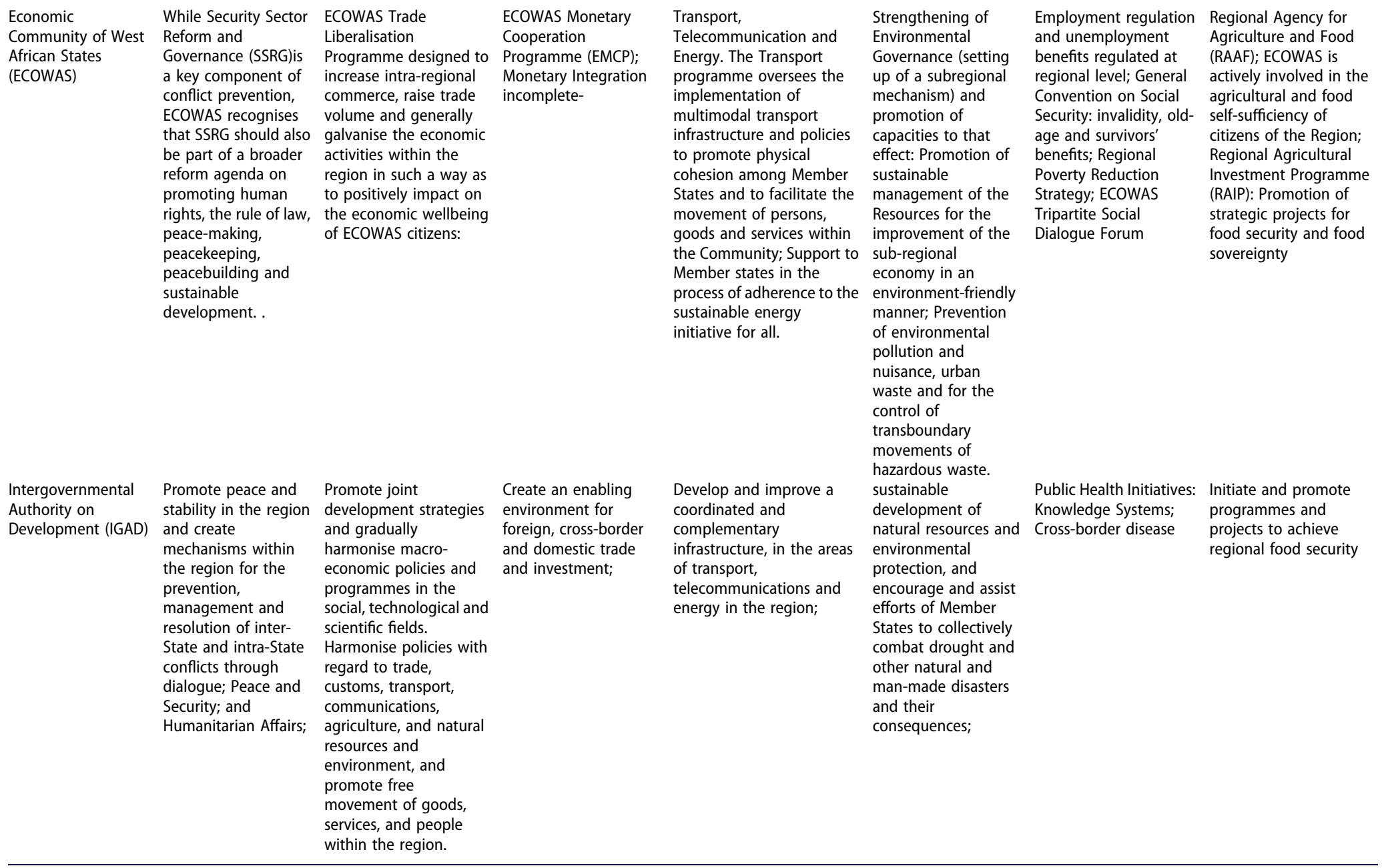


Table 2. Continued.

\begin{tabular}{|c|c|c|c|c|c|c|c|}
\hline & Security policy & $\begin{array}{c}\text { Trade and economic } \\
\text { development }\end{array}$ & Finance & Infrastructure & Natural resources & Social protection & $\begin{array}{l}\text { Agriculture and food } \\
\text { policy }\end{array}$ \\
\hline $\begin{array}{l}\text { Southern Africa } \\
\text { Development } \\
\text { Community (SADC) }\end{array}$ & $\begin{array}{l}\text { The Defence Sector - } \\
\text { focused mostly on } \\
\text { military matters - } \\
\text { responsible for peace, } \\
\text { stability and security; } \\
\text { The State Security } \\
\text { Sector - intelligence/ } \\
\text { national security, } \\
\text { concerned with } \\
\text { threats against } \\
\text { governments/ } \\
\text { Member States; The } \\
\text { Public Security Sector } \\
\text { - protection of civil } \\
\text { society - including } \\
\text { emergency } \\
\text { management, justice, } \\
\text { immigration and } \\
\text { organised crime; The } \\
\text { Police Sector - law } \\
\text { enforcement } \\
\text { agencies responsible } \\
\text { for transnational } \\
\text { organised crimes } \\
\text { such as drug } \\
\text { trafficking, unlawful } \\
\text { possession of } \\
\text { firearms and stock/ } \\
\text { property theft. }\end{array}$ & $\begin{array}{l}\text { Trade Liberalisation and } \\
\text { Consolidation of Free } \\
\text { Trade Area with } \\
\text { COMESA and EAC; Aim } \\
\text { to establish Customs } \\
\text { Union }\end{array}$ & $\begin{array}{l}\text { Harmonising the } \\
\text { financial and } \\
\text { Investment policies of } \\
\text { SADC's Member States } \\
\text { in an effort to build } \\
\text { stronger regional } \\
\text { integration and } \\
\text { encourage the region's } \\
\text { economic } \\
\text { development.; co- } \\
\text { operation regarding } \\
\text { taxation and related } \\
\text { matters within the } \\
\text { SADC region in order } \\
\text { to attract foreign } \\
\text { investment; }\end{array}$ & $\begin{array}{l}\text { Regional infrastructure } \\
\text { investment part of trade } \\
\text { liberalisation and } \\
\text { consolidation of FTA; water } \\
\text { investments part of fight } \\
\text { against poverty }\end{array}$ & $\begin{array}{l}\text { Development, } \\
\text { promotion and } \\
\text { facilitation of } \\
\text { harmonised policies } \\
\text { and programmes } \\
\text { aimed at achieving } \\
\text { effective and } \\
\text { sustainable utilisation } \\
\text { of natural resources } \\
\text { such as water, } \\
\text { wildlife, fisheries, and } \\
\text { forestry; }\end{array}$ & $\begin{array}{l}\text { SADC's mandate is to } \\
\text { promote Investment, } \\
\text { Efficiency, and } \\
\text { Competitiveness in the } \\
\text { global economy and to } \\
\text { improve the quality of } \\
\text { lives of the region's } \\
\text { population. These goals } \\
\text { can only be achieved by } \\
\text { fostering educated, } \\
\text { skilled, healthy, and } \\
\text { productive 'human } \\
\text { resources'. }\end{array}$ & $\begin{array}{l}\text { Development, } \\
\text { promotion and } \\
\text { facilitation of agricultural } \\
\text { policy harmonisation, } \\
\text { taking into account } \\
\text { gender equity in all } \\
\text { strategies and } \\
\text { programmes; Ensuring } \\
\text { sustainable food } \\
\text { security; Development, } \\
\text { promotion and } \\
\text { harmonisation of } \\
\text { biodiversity, } \\
\text { phytosanitary, sanitary, } \\
\text { crop production and } \\
\text { animal husbandry } \\
\text { policies; Development of } \\
\text { measures to increase } \\
\text { agricultural output of } \\
\text { agro-based industries; } \\
\text { Promotion of Trade in } \\
\text { Agricultural Products }\end{array}$ \\
\hline
\end{tabular}


Table 3. Scale for measurement of normative policy coherence for development.

\begin{tabular}{|c|c|c|c|}
\hline Interaction & Name & Explanation & Example \\
\hline+3 & Indivisible & $\begin{array}{l}\text { Intentionally and directly } \\
\text { mutually reinforcing norms }\end{array}$ & $\begin{array}{l}\text { Formal and substantive normative commitments to } \\
\text { transformative development }\end{array}$ \\
\hline+2 & Reinforcing & $\begin{array}{l}\text { Intentionally and indirectly } \\
\text { mutually reinforcing norms }\end{array}$ & $\begin{array}{l}\text { Formal normative commitments to transformative } \\
\text { development }\end{array}$ \\
\hline+1 & Enabling & $\begin{array}{l}\text { Creates conditions that further } \\
\text { sustainable development }\end{array}$ & $\begin{array}{l}\text { General normative discourse in favour of } \\
\text { transformative development }\end{array}$ \\
\hline 0 & Consistent & $\begin{array}{l}\text { No significant positive or } \\
\text { negative interactions. }\end{array}$ & Absence of normative elements in policy debates \\
\hline-1 & Constraining & $\begin{array}{l}\text { General normative resistance to } \\
\text { sustainable development. }\end{array}$ & $\begin{array}{l}\text { General normative discourse for growth-based } \\
\text { development }\end{array}$ \\
\hline-2 & Counteracting & $\begin{array}{l}\text { Unintentionally and/or indirectly } \\
\text { clashing norms }\end{array}$ & $\begin{array}{l}\text { Formal normative commitments that undermine } \\
\text { transformative development through pro-growth } \\
\text { strategies }\end{array}$ \\
\hline-3 & Cancelling & $\begin{array}{l}\text { Intentionally and directly } \\
\text { clashing norms }\end{array}$ & $\begin{array}{l}\text { Formal and substantive normative commitments that } \\
\text { undermine transformative development through } \\
\text { pro-growth strategies. }\end{array}$ \\
\hline
\end{tabular}

Source: Koff, Challenger, and Portillo (2020) Guidelines for Operationalising Policy Coherence for Development (PCD) as a Methodology for the Design and Implementation of Sustainable Development Strategies. Sustainability, 12, 4055.

coherence exists between African regional organisations' migration management and development strategies. This does not, however, represent 'policy coherence for development' as conceptualised above because African regional development strategies are normatively incoherent with the transformative development pursued by the SDGs.

In fact, the analysis presented above highlights the importance of external actors in the definition of African migration and development strategies. In terms of migration, African management policies reflect many of the positions of the EU. The EU originally included migration management as part of the aid conditionality integrated into the 2000 Cotonou Agreement which defined the EU's implementation strategies for the Millennium Development Goals and later, the SDGs. The agreement established the framework for the 2005 Global Approach to Migration and Mobility (GAMM) which prioritises legal migration and 'well-managed mobility', preventing and combatting irregular migration, eradicating trafficking in human beings, and enhancing the external dimension of asylum. This language guides all EU cooperation programs with African regions, such as the Joint Valletta Action Plan and the Regional Indicative Programme for Eastern Africa, Southern Africa and Indian Ocean (EA-SA-IO). Observers of the EU-Africa dialogue on migration such as Bisong (2019), Castillejo (2019) and Van Criekinge (2013) have illustrated how EU cooperation with African regions fulfils the former's policy objectives regarding the prevention of irregular migration at the expense of the latter's needs for free movements of people.

Similarly, despite the passage of the African Union's Agenda 2063 which represents the continent's strategic framework that 'aims to deliver on its goal for inclusive and sustainable development,' regional policies in Africa generally contribute to free-market economic growth which often undermines transformative sustainable development (Fioramonti 2013). More particularly, trade, finance and infrastructure policies are generally growth-based which reflect the interests of international donors more than attention to the well-being of citizens. Within this context, free movement of people is generally framed in terms of labour mobility and its contribution to growth. In this regard, the sectoral policies of Africa's regional organisations seem to normatively undermine the character of development pursued by Agenda 2063 and the SDGs. 
Table 4. Comparative analysis of normative policy coherence for development by regional organisation and policy sector.

\begin{tabular}{|c|c|c|c|c|c|c|c|c|}
\hline & $\begin{array}{l}\text { Security } \\
\text { policy }\end{array}$ & $\begin{array}{c}\text { Trade and economic } \\
\text { development }\end{array}$ & Finance & Infrastructure & $\begin{array}{l}\text { Natural } \\
\text { resources }\end{array}$ & $\begin{array}{c}\text { Social } \\
\text { protection }\end{array}$ & $\begin{array}{l}\text { Agriculture and food } \\
\text { policy } \\
\end{array}$ & Overall \\
\hline African Union (AU) & 0 & -2 & -3 & -1 & -1 & +3 & +3 & -1 \\
\hline $\begin{array}{l}\text { Common Market for Eastern and Southern } \\
\text { Africa (COMESA) }\end{array}$ & -3 & -3 & -3 & -3 & -1 & +1 & 0 & -12 \\
\hline East African Community (EAC) & 0 & -3 & -3 & 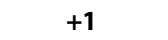 & +3 & +3 & +1 & +2 \\
\hline $\begin{array}{l}\text { Economic Community of Central African States } \\
\text { (ECCAS) }\end{array}$ & 0 & -3 & -2 & -1 & -2 & -1 & 0 & -9 \\
\hline $\begin{array}{l}\text { Economic Community of West African } \\
\text { States (ECOWAS) }\end{array}$ & +3 & +3 & -3 & +1 & +3 & +3 & +3 & +13 \\
\hline $\begin{array}{l}\text { Intergovernmental Authority on Development } \\
\text { (IGAD) }\end{array}$ & 0 & -3 & -3 & -2 & +3 & +1 & +3 & -1 \\
\hline $\begin{array}{l}\text { Southern Africa Development Community } \\
\text { (SADC) }\end{array}$ & 0 & -3 & -3 & -3 & +3 & -3 & +1 & -8 \\
\hline Overall & 0 & -14 & -20 & -8 & +8 & +7 & +11 & -16 \\
\hline
\end{tabular}

Source: Table compiled by author. 


\section{Conclusion}

Noted migration scholar Boubacar Barry recently stated the following during an interview on regional integration and migration: 'there is another protagonist who is often forgotten by the first two [ECOWAS and its member states], they are the peoples of West Africa who have lived in this space for millennia and have their traditions of nomadism and sedentarisation, but also have their tradition of migration through this space for centuries' (Marfaing and Barry 2013).

This article began by questioning the EU'sstated position that migration can be better managed at its source in Africa. The EU has invested billions of euros since 2015 in this logic, providing financial support for migration management programs established with the African Union, African RECs, and African states. Scholars of migration in Africa (see Dick and Schraven 2019) have illustrated how this development aid has undermined sustainable development on the continent through securitisation measures aimed at preventing migrants from coming to Europe. Consequently, this article draws upon Barry's perspective that migration policies should reflect the development needs of African citizens rather than polities. This article supports this view by addressing regional integration and migration through the lens of normative policy coherence for development.

The research presented above has indicated normative incoherence with transformative sustainable development on three levels. First, it has reinforced the view that EU migration management strategies in Africa undermine transformative development. Second, this article has shown how African RECs have implemented policies aimed at free movement of people in support of free trade and customs unions which also seemingly undermine sustainability. The third part of this analysis is the most significant. It contextualises migration discussions by measuring the normative policy coherence for development of AU and African REC policy-making in seven different sectors indicating that regional development strategies in Africa are normatively incoherent with transformative sustainable development.

This pronounced normative policy incoherence for development contributes to a system perpetuating migrant risk and vulnerability in Africa. According to Lorenzo Fioramonti:

The current economic growth-centred paradigm in which Southern African states operate is proving harmful to the social protection of migrants. The political and economic discourse is largely based on a narrow definition of macro-economic growth, which results in a conservative understanding of social protection mechanisms. In most of these countries, social welfare policies are generally viewed as a waste of public money with no direct economic returns. By contrast, a coordinated policy of free movement or managed migration would allow certain states to address critical skills shortages and support economic integration in the region. (Fioramonti 2013)

In fact, the significance of this point goes beyond the well-being of African migrants. It also directly addresses vulnerabilities of African states and African regions. Scholars of regional integration in Africa, such as Castillejo (2019), Rekiso (2017), and Omolo (2019) have documented how regional integration on the continent has promoted freemarket development strategies based on growth more than sustainability. This approach has indeed led to visible benefits. According to the African Development Bank's (AfDB) pre-COVID-19 2020 economic forecast: 
Africa's economic growth has stabilised at 3.4 percent in 2019 and is expected to pick up to 3.9 percent in 2020 and 4.1 percent in 2021 but to remain below historical highs. Growth's fundamentals are also improving, with a gradual shift from private consumption toward investment and exports. For the first time in a decade, investment accounted for more than half the continent's growth, with private consumption accounting for less than one third. (African Development Bank 2020)

Unfortunately, side effects have also occurred as these strategies have compounded poverty issues and inequality. According to the AfDB: 'The 2020 Outlook highlights, however, that growth has been less than inclusive. Only about a third of African countries achieved inclusive growth, reducing both poverty and inequality.' (African Development Bank 2020) These trends are equally present in regional integration studies. Scholars such as Faleye (2016), Adeniran (2014) and Nshimbi, Moyo, and Oloruntoba (2018) have all demonstrated how formal regional integration has been accompanied by informal processes of cross-border integration, including increases in informal cross-border mobility.

Regional development and migration management strategies in Africa are contributing to the perpetuation of parallel systems: one formal, the other informal. In doing so, African regions have demonstrated that they are not better equipped to 'better manage migration at its source' as the EU contends. African regional policy should adopt a normative policy coherence for development framework in order to pursue the transformative development promoted by the SDGs. Otherwise, their migration strategies will perpetuate risk and vulnerability and increase social costs associated with a dystopic migration system. Far from addressing migration crises, the current system seems to be perpetuating them.

\section{Disclosure statement}

No potential conflict of interest was reported by the authors.

\section{References}

Abebe, Tsion Tadesse. 2017. Migration Policy Frameworks in Africa. Pretoria, S.A: Institute for Security Studies.

Adeniran, Adebusuyi Isaac. 2014. Migration and Regional Integration in West Africa: A Borderless ECOWAS. London: Palgrave Macmillan.

African Development Bank. 2020. "African Economic Outlook 2020." https://www.afdb.org/en/ knowledge/publications/african-economic-outlook\#: :text=Africa's\%20economic\%20growth\% 20has\%20stabilized,to\%20remain\%20below\%20historical\%20highs.\&text=Only\%20about\%20a \%20third\%20of,reducing\%20both\%20poverty\%20and\%20inequality. Accessed 15 June 2020.

African Union. n.d. "Key Transformational Outcomes of Agenda 2063." Accessed June 16, 2020. https://au.int/en/agenda2063/outcomes.

Awumbila, Mariana. 2017. Drivers of Migration and Urbanization in Africa: Key Trends and Issues. UN/ POP/EGM/2017/12. New York: United Nations.

Bakewell, Oliver. 2007. "Keeping Them in Their Place: The Ambivalent Relationship Between Development and Migration in Africa." International Migration Institute Working Paper 8. Oxford, UK: Oxford University.

Barana, Luca. 2017. "The EU Trust Fund for Africa and the Perils of a Securitized Migration Policy" IAI Commentaries 17/31. Rome: Instituto Affari Internazionali.

Bisong, Amanda. 2019. "Trans-regional Institutional Cooperation as Multilevel Governance: ECOWAS Migration Policy and the EU." Journal of Ethnic and Migration Studies 45 (8): 1294-1309. doi:10. 1080/1369183X.2018.1441607. 
Carbone, Maurizio. 2008. "Mission Impossible: The European Union and Policy Coherence for Development." Journal of European Integration 30 (3): 323-342. doi:10.1080/07036330802144992.

Carbone, Maurizio, and Niels Keijzer. 2016. "The European Union and Policy Coherence for Development: Reforms, Results, Resistance." European Journal of Development Research 28 (1): 30-43. doi:10.1057/ejdr.2015.72.

Castillejo, Clare. 2019. "The Influence of EU Migration Policy on Regional Free Movement in the IGAD and ECOWAS Regions." Discussion Paper. https://doi.org/10.23661/DP11.2019.

Compton, Robert. 2013. "Comparative Regional Integration in SADC and ASEAN." Regions \& Cohesion 3 (1): 5-31. doi:10.3167/reco.2013.030102.

Crush, Jonathan, and Wade C. Pendleton, Institute for Democracy in South Africa, and Southern African Migration Project. 2004. Regionalizing Xenophobia?: Citizen Attitudes to Immigration and Refugee Policy in Southern Africa.

Deacon, Bob, Lorenzo Fioramonti, and Sonja Nita. 2013. "Regions Without Borders? Regional Governance, Migration, and Social Protection in Africa and Europe." Regions and Cohesion 3 (3): 1-7. doi:10.3167/reco.2013.030301.

Deacon, Bob and Sonia Nita. 2013. "Regional Social Integration and Free Movement Across Borders: The Role of Social Policy in Enabling and Preventing Access to Social Entitlements by CrossBorder Movers. European Union and Southern Africa Compared." Regions and Cohesion 3 (1): 32-61. doi:10.3167/reco.2013.030103.

Degli Uberti, Stefano, Philippe De Lombaerde, Sonja Nita, and Elettra Legovini. 2015. "Analyzing Intra-Regional Migration in Sub-Saharan Africa: Statistical Data Constraints and the Role for Regional Organizations." Regions and Cohesions 5 (2): 77-113. doi:10.3167/reco.2015.050204.

Dick, Eva, and Benjamin Schraven. 2019. "Regional Cooperation on Migration and Mobility: Insights from two African Regions." AnthroSource 2 (1): 102-118. doi:10.1002/j.2573-508X.2018.tb000011.x.

Eriksson, Jill. 2013. "Addressing Urban Poverty in West Africa: What is the Potential of Sub-Regional Integration and Cooperation?" Ph.D. diss., University of Luxembourg.

Espinosa, Shirlita Africa. 2013. "The World Social Forum on Migrations 2012: Consolidating Efforts Towards an Equitable Society." Regions and Cohesion 3 (3): 146-154. doi:10.3167/reco.2013.030309.

European Commission. 2016. "The EU and the Refugee Crisis." http://publications.europa.eu/ webpub/com/factsheets/refugee-crisis/en/ (accessed 10 October 2017).

Faleye, Olukayode A. 2016. "Regional Integration from 'Below' in West Africa: A Study of Transboundary Town-Twinning of Idiroko (Nigeria) and Igolo (Benin)." Regions and Cohesion 6 (3): 1-19. doi:10.3167/reco.2016.060301.

Fioramonti, Lorenzo. 2013. "Round Table Report: Advancing Regional Social Integration, Social Protection, and the Free Movement of People in Southern Africa." Regions and Cohesion 3 (3): 141-145. doi:10.3167/reco.2013.030308.

Flahaux, Marie-Laurence, and Hein De Haas. 2016. "African Migration: Trends, Patterns, Drivers." Comparative Migration Studies 4 (1): 1. doi:10.1186/s40878-015-0015-6.

Forster, Jacques, and Eds Olav Stokke. 1999. Policy Coherence in Development co-Operation. London: Frank Cass.

Gagnon, Jason, and David Khoudour-Castéras. 2012. "South-South Migration in West Africa: Addressing the Challenge of Immigrant Integration." OECD Development Centre Working Paper 312. Paris: OECD.

Grabel, Ilene. 2007. "Policy Coherence or Conformance? The New World Bank-International Monetary Fund-World Trade Organization Rhetoric on Trade and Investment in Developing Countries." Review of Radical Political Economics 39 (3): 335-341. doi:10.1177/0486613407305281.

Graham, Suzanne, and Victoria Graham. 2019. "Quality Political Participation and the SDGs in African Small Island Developing States." Regions \& Cohesion 9 (2): 1-30. doi:10.3167/reco.2019.090202.

Häbel, Sandra. 2020. "Normative Policy Coherence for Development and Policy Networks: EU Networks in Vietnam." Regions \& Cohesion 10 (1): 1-21. doi:10.3167/reco.2020.100102.

Hintjens, Helen. 2019. "Failed Securitisation Moves During the 2015 'Migration Crisis." International Migration 57 (4): 181-196. doi:10.1111/imig.12588.

Hoebink, Paul. 2004. "Evaluating Maastricht's Triple C: The "C" of Coherence." In The Treaty of Maastricht and Europe's Development Co-Operation, edited by Paul Hoebink, 183-218. Amsterdam: Aksant. 
Hujo, Katja. 2013. "Linking Social Policy, Migration, and Development in a Regional Context: The Case of Sub-Saharan Africa." Regions and Cohesion 3 (3): 30-55. doi:10.3167/reco.2013.030303.

International Organisation for Migration. undated. "Missing Migrants: Tracking Deaths Along Migratory Routes." Accessed October 19, 2017. https://missingmigrants.iom.int/mediterranean. Iroanya, Richard, Patrick Dzimiri, and Edith Phaswana. 2018. "Human Rights-Based Service Delivery." Regions and Cohesion 8 (2): 1-26. doi:10.3167/reco.2018.080202.

Koff, Harlan. 2017a. "Diaspora Philanthropy in the Context of Policy Coherence for Development: Implications for the Post-2015 Sustainable Development Agenda." International Migration 55 (1): 5-19. doi:10.1111/imig.12277.

Koff, Harlan. 2017b. "Policy Coherence for Development and Migration: Analyzing US and EU Policies Through the Lens of Normative Transformation." Regions and Cohesion 7 (2): 5-33. doi:10.3167/reco.2017.070202.

Koff, Harlan, Jun'ichi Akashi, and Midori Okabe. 2018. "The EU-Japan Security Dialogue and Migration: A Search for Common Ground." In EU-Japan Security Cooperation: Trends and Prospects, edited by Emil J. Kirchner, and Han Dorussen, 203-222. London, UK: Routledge.

Koff, Harlan, Antony Challenger, and Israel Portillo. 2020. "Guidelines for Operationalizing Policy Coherence for Development (PCD) as a Methodology for the Design and Implementation of Sustainable Development Strategies." Sustainability 12 (10): 4055. doi:10.3390/su12104055.

Koff, Harlan, and Carmen Maganda. 2016. "The EU and The Human Right to Water and Sanitation: Normative Coherence as the Key to Transformative Development." The European Journal of Development Research 28 (1): 91-110. doi:10.1057/ejdr.2015.77.

Marfaing, Laurence, and Boubacar Barry. 2013. "Anta Diop, Dakar: Mobilité des nomades et des sédentaires dans l'espace CEDEAO." Regions and Cohesion 3 (3): 155-166. doi:10.3167/reco. 2013.030310.

Martens, Jens. 2015. "Benchmarks for a Truly Universal Post-2015 Agenda for Sustainable Development." Regions \& Cohesion 5 (1): 73-94. doi:10.3167/reco.2015.050105.

Matthews, Alan. 2008. "The European Union's Common Agricultural Policy and Developing Countries: The Struggle for Coherence." Journal of European Integration 30 (3): 381-399. doi:10. 1080/07036330802141998.

Mbanda, Vandudzai, and Willem Fourie. 2019. "The 2030 Agenda and Coherent National Development Policy: In Dialogue with South African Policymakers on Policy Coherence for Sustainable Development." Sustainable Development. doi:10.1002/sd.2025.

Moldes-Anaya, Sergio, Francisco Jiménez Aguilar, and Francisco Jiménez Bautista. 2019. "Percepción de la inmigración en España desde la Investigación en Conflictos." Regions \& Cohesion 9 (2): $58-82$.

Moore, Candice. 2013. Regional Integration and Social Cohesion: Perspectives from the Developing World. Brussels: Peter Lang.

Nilsson, Mans. et al. 2018. "Mapping Interactions between the Sustainable Development Goals: Lessons Learned and Ways Forward." Sustainability Science 13: 1489-1503. doi:10.1007/s11625018-0604-z.

Nhengu, Dudziro. 2020. "The Health of Migrants as a Global Peace and Security Agenda." Regions and Cohesion 10 (2): 1-20. doi:10.3167/reco.2020.100202.

Nita, Sonja. 2013. "Regional Free Movement of People: The Case of African Regional Economic Communities." Regions and Cohesion 3 (3): 8-29. doi:10.3167/reco.2013.030302.

Nono, Guy Marcel. 2013. "Regional Integration and Free Movement in Central Africa Integración Regional y Libre Circulación En África Central L'intégration Régionale et La Libre Circulation En Afrique Centrale." Regions and Cohesion 3 (3): 123-140. doi:10.3167/reco.2013.030307.

Nshimbi, Christopher Changwe, Inocent Moyo, and Samuel Ojo Oloruntoba. 2018. "Borders, Informal Cross-Border Economies and Regional Integration in Africa." Africa Insight 10: 3-10.

Nyberg-Sorensen, Ninna. 2012. "Revisiting the Migration-Development Nexus: From Social Networks and Remittances to Markets for Migration Control." International Migration 50 (3): 61-76.

Nyberg-Sorensen, Ninna, Nicolas Van Hear, and Poul Engberg-Perdersen. 2002. The Migration Development Nexus: Evidence and Policy Options. Geneva: IOM.

OECD. 2005. Policy Coherence for Development: Promoting Institutional Good Practice. Paris: OECD. 
OECD. 2019. Policy Coherence for Sustainable Development 2019: Empowering People and Ensuring Inclusiveness and Equality. Paris: OECD. https://www.oecd-ilibrary.org/sites/a90f851f-en/1/2/1/ index.html?itemld=/content/publication/a90f851f-en\&_csp_=73b15b213fdb1ee6ffc1405b658b1 $78 f \&$ itemIGO=oecd\&itemContentType=book. Accessed 20 March 2020.

Omolo, Christopher Otieno. 2019. "The Africa-EU Relations and Regionallntegration in Africa: Reassessing EU's Influence on Africa's Integration Project(s)." L'Europe en Formation 388: 27-50. ISSN 0014-2808.

Oucho, John. 2013. "Prospects for Free Movement in the East African Community." Regions and Cohesion 3 (3): 103-122. doi:10.3167/reco.2013.030306.

Picciotto, Roberto. 2004. "Aid and Conflict: The Policy Coherence Challenge. Conflict." Security \& Development 4 (3): 543-562. doi:10.1080/1467880042000320069.

Rekiso, Zinabu Samaro. 2017. "Rethinking Regional Economic Integration in Africa as If Industrialization Mattered." Structural Change and Economic Dynamics 43 (December): 87-98. doi:10.1016/j.strueco.2017.10.001.

SADC. 2017. "No one should be left behind, says SADC as the World Commemorates International Day for the Eradication of Poverty." Accessed June 15, 2020. https://www.sadc.int/news-events/ news/no-one-should-be-left-behind-says-sadc-world-commemorates-international-dayeradication-poverty/.

Thede, Nancy. 2013. "Policy Coherence for Development and Securitisation: Competing Paradigms or Stabilising North-South Hierarchies?" Third World Quarterly 34 (5): 784-799. doi:10.1080/ 01436597.2013.800752.

United Nations. 2017. "'Population and Vital Statistics Report, January 2017." Statistical Papers United Nations (Ser. A)." Population and Vital Statistics Report, doi:10.18356/92630ac3-en.

United Nations. n.d. "Transforming Our World: The 2030 Agenda for Sustainable Development." New York: UN. Accessed September 24, 2020. https://sdgs.un.org/2030agenda.

Van Criekinge, Tine. 2013. "The EU-Africa Migration Partnership: The Limits of the EU's External Dimension of Migration in Africa." In The European Union in Africa: Incoherent Policies, Asymmetrical Partnership, Declining Relevance?, edited by M. Carbone, 258-285. Oxford: Oxford University Press.

World Bank. 2010. Migration and Remittances Factbook 2011. Washington, DC: Development Prospects Group, World Bank.

Zeigermann, Ulrike. 2020. "Policy Coherence for Sustainable Development: A Promising Approach for Human Security in Fragile States." Journal of Peacebuilding and Development, doi:10.1177/ 1542316620909077. 
Appendix. Member states of seven regional organisations examined in this article.

\begin{tabular}{|c|c|c|c|c|c|c|c|}
\hline & $A U$ & COMESA & EAC & ECCAS & ECOWAS & IGAD & SADC \\
\hline $\begin{array}{c}\text { Member } \\
\text { States }\end{array}$ & $\begin{array}{l}\text { Algeria, Angola, Benin, } \\
\text { Botswana, Burkina Faso, } \\
\text { Burundi, Cameroon, Cabo } \\
\text { Verde, Central African } \\
\text { Republic, Chad, Comoros, } \\
\text { Congo, the Democratic } \\
\text { Republic of Congo, Cote } \\
\text { d'Ivoire, Djibouti, Equatorial } \\
\text { Guinea, Egypt, Eritrea, } \\
\text { Ethiopia, Gabon, Gambia, } \\
\text { Ghana, Guinea, Guinea- } \\
\text { Bissau. Kenya, the Kingdom } \\
\text { of Lesotho, Liberia, Libya, } \\
\text { Madagascar, Malawi, Mali, } \\
\text { Mauritania, Mauritius, } \\
\text { Morocco, Mozambique, } \\
\text { Namibia, Niger, Nigeria, } \\
\text { Rwanda, Saharawi Arab } \\
\text { Democratic Republic, Sao } \\
\text { Tome and Principe, Senegal, } \\
\text { Seychelles, Sierra Leone, } \\
\text { Somalia, South Africa, South } \\
\text { Sudan, Sudan, Kingdom of } \\
\text { Swaziland, Tanzania, Togo, } \\
\text { Tunisia, Uganda, Zambia } \\
\text { and Zimbabwe. }\end{array}$ & $\begin{array}{l}\text { Burundi, Comoros, Congo, } \\
\text { Dem Rep., Djibouti, } \\
\text { Egypt, Eritrea, Ethiopia, } \\
\text { Kenya, Libya, } \\
\text { Madagascar, Malawi, } \\
\text { Mauritius, Rwanda, } \\
\text { Seychelles, Sudan, } \\
\text { Swaziland, Uganda, } \\
\text { Zambia, and Zimbabwe. }\end{array}$ & $\begin{array}{l}\text { Burundi, } \\
\text { Kenya, } \\
\text { Rwanda, } \\
\text { South Sudan, } \\
\text { Uganda and } \\
\text { United } \\
\text { Republic of } \\
\text { Tanzania. }\end{array}$ & $\begin{array}{l}\text { Angola, Burundi, } \\
\text { Cameroon, Central } \\
\text { African Republic, } \\
\text { Chad, Democratic } \\
\text { Republic of Congo, } \\
\text { Equatorial Guinea, } \\
\text { Gabon, Republic of } \\
\text { the Congo, São Tomé } \\
\text { and Príncipe }\end{array}$ & $\begin{array}{l}\text { Benin, Burkina Faso, } \\
\text { Cabo Verde, Cote } \\
\text { d'Ivoire, The } \\
\text { Gambia, Ghana, } \\
\text { Guinea, Guinea- } \\
\text { Bissau, Liberia, } \\
\text { Mali, Niger, } \\
\text { Nigeria, Senegal, } \\
\text { Sierra Leone, and } \\
\text { Togo }\end{array}$ & $\begin{array}{l}\text { Djibouti, } \\
\text { Ethiopia, } \\
\text { Eritrea, } \\
\text { Kenya, } \\
\text { Somalia, the } \\
\text { Sudan, South } \\
\text { Sudan and } \\
\text { Uganda. }\end{array}$ & $\begin{array}{l}\text { Angola, Botswana, } \\
\text { Comoros, Democratic } \\
\text { Republic of Congo, } \\
\text { Eswatini, Lesotho, } \\
\text { Madagascar, Malawi, } \\
\text { Mauritius, Mozambique, } \\
\text { Namibia, Seychelles, } \\
\text { South Africa, Tanzania, } \\
\text { Zambia and Zimbabwe }\end{array}$ \\
\hline
\end{tabular}

Source: Table compiled by author. 